\title{
A new genus record of an enigmatic linyphiid spider (Aranei: Linyphiidae) from the Russian Far East
}

\section{Новая находка рода загадочных пауков-линифиид (Aranei: Linyphiidae) с Аальнего Востока России}

\author{
Yuri M. Marusik ${ }^{1,2}$, Mikhail M. Omelko ${ }^{3,4}$ \\ Ю.М. Марусик ${ }^{1,2}$, М.М. Омелько
}

\footnotetext{
${ }^{1}$ Institute for Biological Problems of the North RAS, Portovaya Str.18, Magadan 685000, Russia. E-mail: yurmar@mail.ru

${ }^{2}$ Department of Zoology \& Entomology, University of the Free State, Bloemfontein 9300, South Africa

${ }^{3}$ Federal Scientific Center of East Asia Terrestrial Biodiversity, Far Eastern Branch, Russian Academy of Sciences, Vladivostok 690022, Russia. E-mail: omelkom@gmail.com

${ }^{4}$ Far Eastern Federal University, Laboratory of ecology and evolutionary biology of aquatic organisms (LEEBAO), School of Natural Sciences, Vladivostok 690091, Russia.

${ }^{1}$ Институт биологических проблем Севера ДВО РАН, Портовая 18, Магадан 685000, Россия.

${ }^{3}$ Федеральный научный центр Биоразнообразия наземной биоты Восточной Азии ДВО РАН, Владивосток 690022, Россия.

${ }^{4}$ Дальневосточный Федеральный Университет, Лаборатория экологии и эволюционной биологии водных организмов (ЛЭБВО), Школа Естественных Наук, Владивосток 690091, Россия.
}

KEY WORDS: Araneae, Araneidae, Lazo Reserve, Maritime Province, redescription, Sinolinyphia.

КЛЮЧЕВЫЕ СЛОВА: Araneae, Araneidae, Лазовский заповедник, Приморский край, переописание, Sinolinyphia.

ABSTRACT. The monotypic genus Sinolinyphia Wunderlich et Li, 1995 and its type species $S$. henanensis (Hu, Wang et Wang, 1991), previously known from northeastern China, are reported from the Maritime Province of Russia. Detail figures are provided to illustrate habitus and copulatory organs of this species, the relationship of the genus is briefly discussed, and the known distribution records mapped.

How to cite this paper: Marusik Yu.M., Omelko M.M. 2021. A new genus record of an enigmatic linyphiid spider (Aranei: Linyphiidae) from the Russian Far East // Arthropoda Selecta. Vol.30. No.4. P.565-571. doi: 10.15298/arthsel.30.4.13

PЕЗЮME. Sinolinyphia henanensis (Hu, Wang et Wang, 1991) из монотипического рода Sinolinyphia Wunderlich et Li, 1995, ранее известный из СевероВосточного Китая, указан для Приморского края России. Даны подробные изображения внешнего вида и копулятивных органов $S$. henanensis. Обсуждается положение рода. Находки вида показаны на карте.

\section{Introduction}

Two decades ago, the first author received one female araneoid specimen from the Lazo Reserve (Maritime Province of Russia) resembling the araneid genus Chorizopes O. Pickard-Cambridge, 1871 (Oliger et al., 2002). Since then, it has been reported in several papers as either "Chorizopes ? sp." (Oliger et al., 2002;
Marusik, 2009a) or "Chorizopes sp." (Marusik, 2009b). The specimen has a bulging thoracic part and an abdominal conical extension, somewhat similar to that in Chorizopes, but still, it has a different configuration of epigyne and spination pattern. Recently, we received new material containing both sexes, which made us realize that this species does not belong to Chorizopes, and it is not an araneid at all. Even though the male palp has a flexible paracymbium like those in Linyphiidae (although of unique shape), both sexes have posterior abdominal conical outgrowths unknown in the Holarctic members of the family. Recently, while searching through the literature, we realized that our specimens belong to Sinolinyphia henanensis (Hu, Wang et Wang, 1991), a species that has been considered in two araneid genera Hypsosinga Ausserer, 1871 and Araneus Clerck, 1757 before finally being classified in the monotypic linyphiid genus Sinolinyphia Wunderlich et Li, 1995. Although $S$. henanensis has been considered in nine taxonomic papers, details of its morphology have never been properly illustrated. In this paper we redescribe the species in detail and discuss the relationships of the genus.

\section{Material and methods}

Specimens were photographed using a Canon EOS 7D camera, attached to an Olympus SZX16 stereomicroscope or to the eye piece of an Olympus $\mathrm{BH} 2$ transmission microscope at the Zoological Museum of the University of Turku. Digital images were montaged using CombineZP and Heli- 


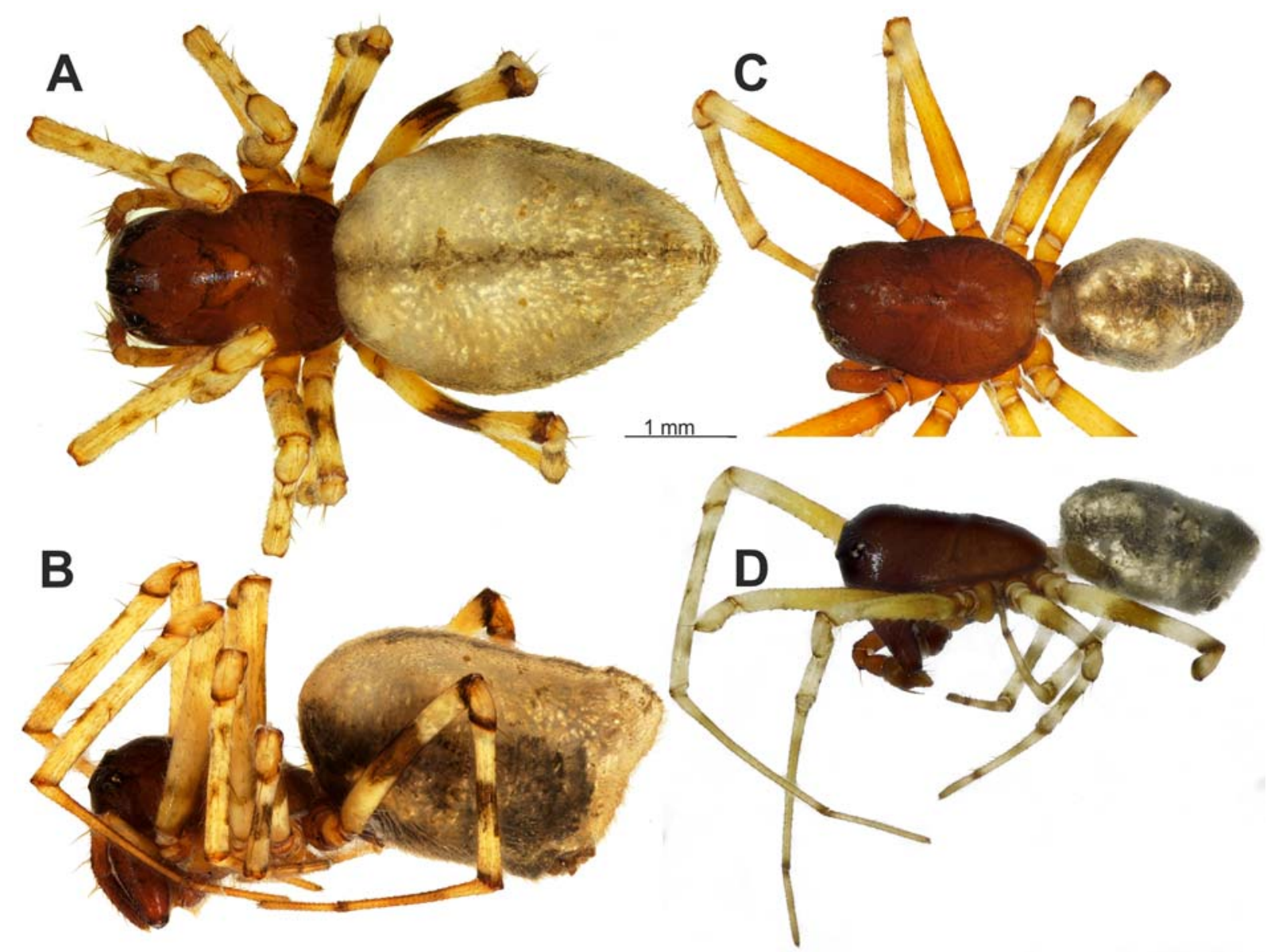

Fig. 1. Habitus of Sinolinyphia henanensis. A-B - female, dorsal and lateral; C-D - male, dorsal and lateral.

Рис. 1. Внешний вид Sinolinyphia henanensis. А-В - самка, дорзально и латерально; C-D - самец, дорзально и латерально.

con focus 3.10 image stacking software and edited using CorelDraw graphic design software. Lengths of leg segments were measured on the dorsal side and listed as: total length (femur, patella, tibia, metatarsus, tarsus).

Abbreviations: eyes: ALE — anterior lateral eye, AME anterior median eye, PLE - posterior later eye, PME posterior median eye.

\section{Taxonomy}

\section{Sinolinyphia Wunderlich et Li, 1995}

Type species Sinolinyphia cyclosoides Wunderlich et Li, 1995 from Hefen, Hubei Province of China.

DIAGNOSIS. The genus and species significantly differ from all other linyphiids occurring in the Holarctic by having a dorsal abdominal conical extension, giving it a nonoval shape in lateral view (Fig. 1B, D) (vs. oval). Carapace has unusual proportions: the thoracic part is only 1.2 times wider than the cephalic part ( $v s .>1.2)$. The male palp is most similar to that of Frontinellina van Helsdingen, 1969 (Fig. 4E-H): both genera have similar shape of lamella, extending toward ectal side of the palp and hiding ventral margin of the tegulum, triangular paracymbium, cymbium tapering toward the tip, and embolus bending clockwise (vs. tegulum not hidden under lamella, cymbium oval, embolus bending anticlockwise in the related Linyphia Latreille, 1804 and Neriene Blackwall, 1833). Males can be easily distinguished by the shape of lamella, course of the embolus and its tip directed anteriorly in Sinolinyphia (vs. mesally in Frontinellina), and also by the shape of paracymbium, and palpal tibia longer than wide (vs. wider than long). Epigynes in the generotypes of the two genera are also somewhat similar, but Sinolinyphia has distinct and round copulatory openings ( $v s$. indistinct).

RELATIONSHIPS. Wunderlich \& Li [1995] mentioned that the epigyne of Sinolinyphia is similar to those of Frontinella F.O. Pickard-Cambridge, 1902, but without indicating any particular species. Apparently they compared it with $F$. huachuca benevola Gertsch et Davis, 1946 which has a similar epigyne. It seems that this species and both of its subspecies are misplaced in Frontinella, because they lack the modified male palpal patella and the strong, spine-like setae on cymbium as present in F. laeta (O. Pickard-Cambridge, 1898), the generotype. The type species has not been redescribed and is known only from two publications over 110 years old. Some species currently considered in Frontinella have similar lamella of the male palp and elongated tibia (longer than wide), although the type of embolus, its anticlockwise direction and paracymbium are rather different. To our mind, Sinolinyphia is close to Frontinellina due 


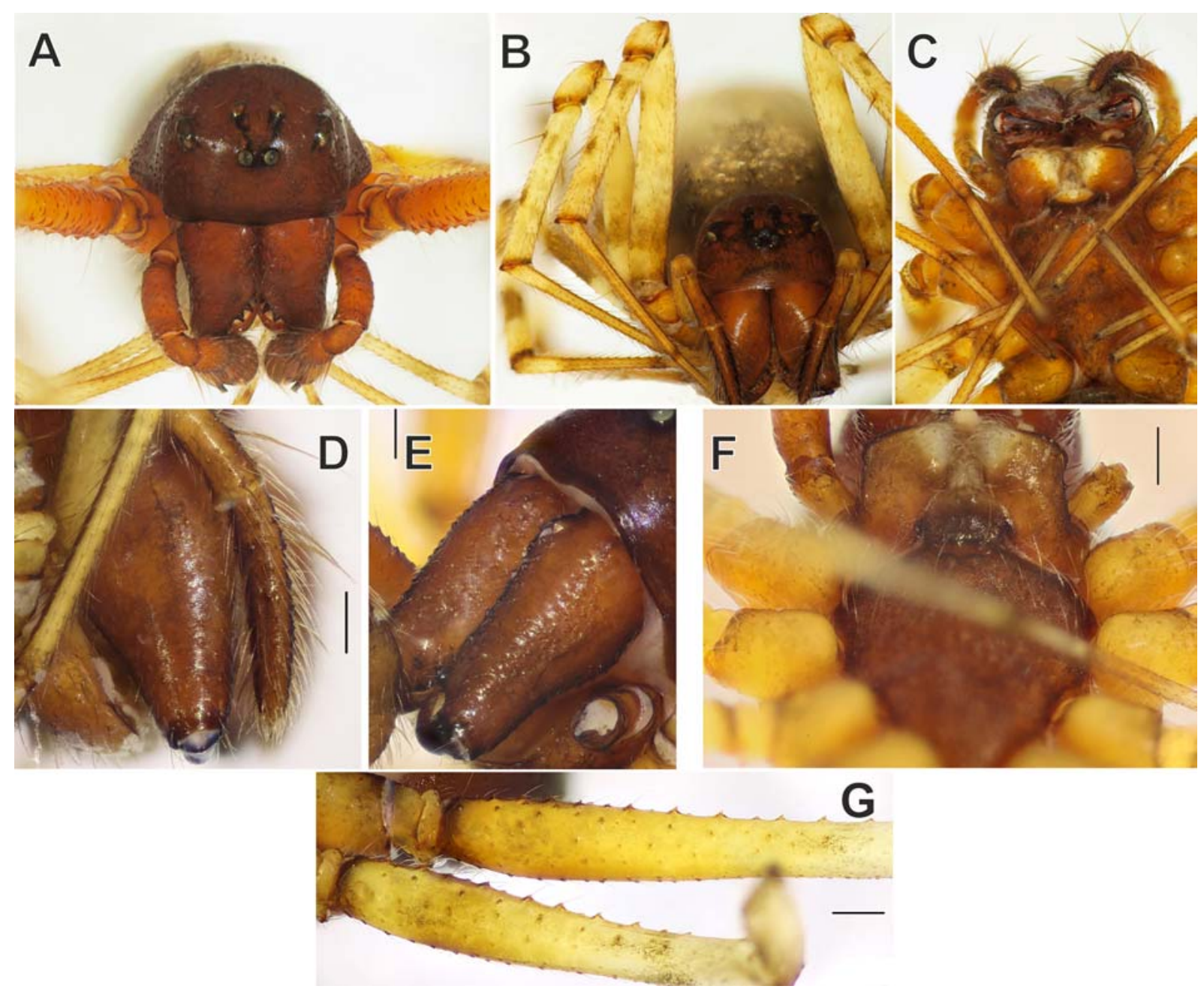

Fig. 2. Somatic characters of Sinolinyphia henanensis, male (A, E-G) and female (B-D). A-B - prosoma, anterior; C, F - prosoma, ventral; D-E - chelicerae, showing stridulatory files; G - male legs I-II showing spine-like bases of setae. Scale $0.2 \mathrm{~mm}$.

Рис. 2. Соматические признаки Sinolinyphia henanensis, самец (A, E-G) и самка (B-D). А-B - головогрудь самца и самки, спереди; С - головогрудь самки, вентрально; D-E - хелицеры самки и самца, показаны стридуляционные борозды; F головогрудь самца, вентрально; G - бёдра ног I-II самца, показаны шиповидные основания волосков. Масштаб 0,2 мм.

to the similar shape of lamella (cf. Fig. 4A-B, E-F), embolus bent clockwise on the left palp (see Figs 3A-B, D, 4F, $\mathrm{H}$ ), and lamella partly hiding the tegulum (Figs 3D, 4G)

NOTE. Frontinella, a genus with the generotype from Mexico is currently known by 10 species, eight of which occur in the New World (Nearctic and Neotropical Realms) and two are distributed in China, F. hubeiensis Li et Song, 1993 and F. zhui Li et Song, 1993. The Chinese species differ from the generotype and, judging by the published illustrations, are not related to each other.

COMPOSITION. Type species only.

Sinolinyphia henanensis (Hu, Wang et Wang, 1991) Figs $1-3,4 \mathrm{~A}-\mathrm{D}, 5,6$.

Hypsosinga henanensis $\mathrm{Hu}$ et al., 1991: 39, f. 5-7 (†). Sinolinyphia cyclosoides Wunderlich, Li, 1995: 336, f. 1-8 $\left(\bigcirc^{\top}+\right)$

Araneus henanensis: Yin et al., 1997: 197, f. 114a-h (T from Hypsosinga).

Sinolinyphia cyclosoides: Song et al., 1999: 204, f. 116E-F ( ${ }^{7}+$ ).
Araneus henanensis: Song et al., 1999: 239, f. 138C-D, 148D ( + ).

Sinolinyphia henanensis: Zhu et al., 2005: 502, f. A-E (T from Araneus). Sinol
$\left(\sigma^{\top}+\right)$.

Sinolinyphia henanensis: Zhu, Zhang, 2011: 148, f. 98A-F

Sinolinyphia cyclosoides: Yin et al., 2012: 553, f. 265a-c (+). Araneus henanensis: Yin et al., 2012: 606, f. 292a-h (+).

DISTRIBUTION RECORDS (all refer to the same specimen): Chorizopes? sp.: Oliger et al., 2002: 94; Marusik, 2009a: 98. Chorizopes sp.: Marusik, 2009b: 381.

MATERIAL EXAMINED: RUSSIA, Maritime Prov., Lazo Reserve, $3 \mathrm{~km}$ from Pashegou (=Olenya) Bay, mixed forest in valley of mountain creek, in herbs, 13.08.1981 (T. Oliger) 1웅 same province, south part, label data lost, $10^{\top} 3$ 우요.

DIAGNOSIS. Same as for genus.

DESCRIPTION. Male. Total length 4.13. Carapace 2.13 long, 1.43 wide. Carapace brown with thin radial stripes from fovea to margins; cephalic part raised behind PME, higher than thoracic (Fig. 1D); cephalic part only 1.2 times thinner than thoracic one; fovea oval, deep; in anterior view carapace rounded with high clypeus, 3.3 times longer than 



Fig. 3. Male palp of Sinolinyphia henanensis. A - ventro-ectal; B - ventral; C - ectal; D - ventro-ental; E - ental. Scale $0.2 \mathrm{~mm}$. Abbreviations: $E a$ - ectal arm of lamella, $E m$ - embolus, $P c$ - paracymbium, $T p$ - tail piece of lamella.

Рис. 3. Пальпа самца Sinolinyphia henanensis. А — вентро-эктально; В — вентрально; С — эктально; D — вентро-энтально; Е энтально. Масштаб 0,2 мм.

Сокращения: $E a$ - ретролатеральная ветвь ламеллы, $E m-$ эмболюс, $P c$ - парацимбиум, $T p-$ хвост ламеллы.

AME diameter (Fig. 2A). PME almost round, separated by 1.1 diameters. AME separated by less than diameter. AME spaced from PME by 2 diameters. PME "connected" to AME by blackish stripe. Chelicera brown, with 3 promarginal teeth (one large and 2 much smaller), posterior margin with 4 teeth gradually decreasing in size toward fang. Maxil- la with parallel sides, slightly inclined, twice longer than labium (Fig. 2F). Labium rebordered. Sternum subtriangular with long rear projection between coxae IV.

Femora, metatarsi and tarsi spineless. Tibiae I-IV with 2 dorsal spines, patellae I-IV with 1 dorsal spine. Tibia I 1p, 2r; II 2r; III-IV without lateral spines. 

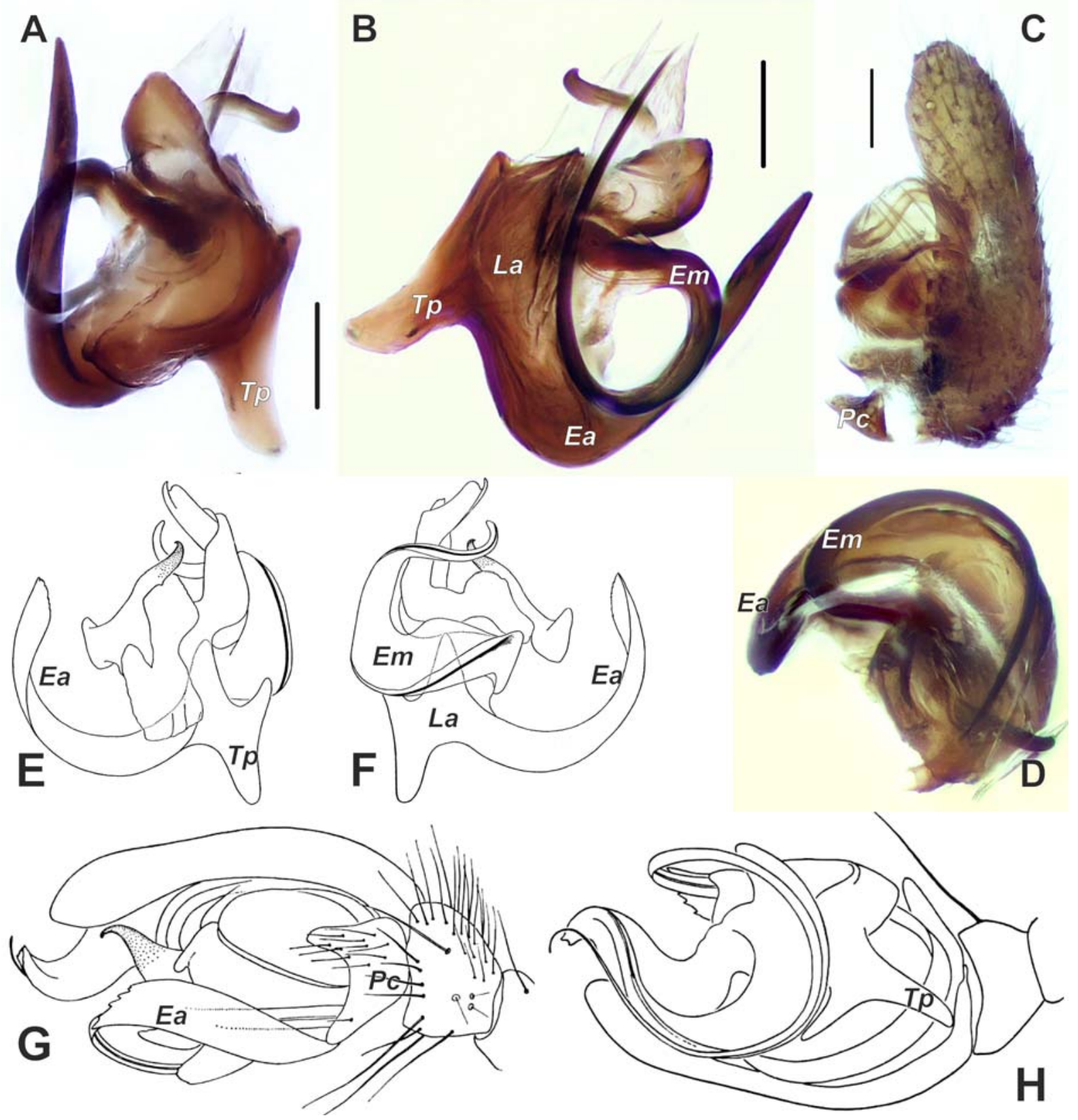

Fig. 4. Male palp of Sinolinyphia henanensis (A-D) and Frontinellina frutetorum (E-H). A-B, E-F - embolic division, different aspects; C - cymbium and bulb with dissected embolic division, lateral; D — embolic division, anterior; G-H - whole terminal part of the palp, ectal and ental. E-H - after van Helsdingen (1970). Scale $0.1 \mathrm{~mm}$.

Abbreviations: $E a$ - ectal arm of lamella, Em - embolus, $L a$ - lamella, $P c$ — paracymbium, $T p$ - tail piece of lamella.

Рис. 4. Пальпа самца Sinolinyphia henanensis (A-D) и Frontinellina frutetorum (E-H). А-B, Е-F - эмболюсный отдел, разные ракурсы; C - цимбиум и бульбус с удаленным эмболюсным отделом, латерально; D — эмболюсный отдел, спереди; G-H терминальная часть пальпы целиком, эктально и энтально. E-H - по van Helsdingen (1970). Масштаб 0,1 мм.

Сокращения: $E a$ - ретролатеральная ветвь ламеллы, $E m$ - эмболюс, $L a$ - ламелла, $P c$ - парацимбиум, $T p-$ хвост ламеллы.

Femora I-II blackish proximally, color gradually changing from light brown to yellow toward patella. Patellae I-II yellow with black anterior edge. Tibiae I-II yellowish with indistinct gray spots. Metatarsi in all legs brown with black tips. Tarsi brown. Femora III-IV like I-II, but with wide black ring in middle part and black tips. Tibia III-IV with more contrasting coloration than in leg I-II. Ventral side of femora with setae standing on spine-like bases (Fig. 2G).
Abdomen egg shaped, dorsum longer than venter, with kind of extension; book lungs dark; venter and sides grayish. Dorsal side whitish with wide gray median band.

Measurements of leg: I: $7.65(2.13,0.5,1.85,2.03$, $1.15)$, II: $6.5(1.88,0.53,1.5,1.65,0.95)$, III: 4.8 (1.38, $0.45,1.05,1.28,0.65)$, IV: $6.68(1.9,0.5,1.5,1.8,0.98)$.

Palp as in Fig. 3A-E, 4A-D; femur thick, ca. 3.3 times longer than wide, longer than cymbium or patella+tibia; 

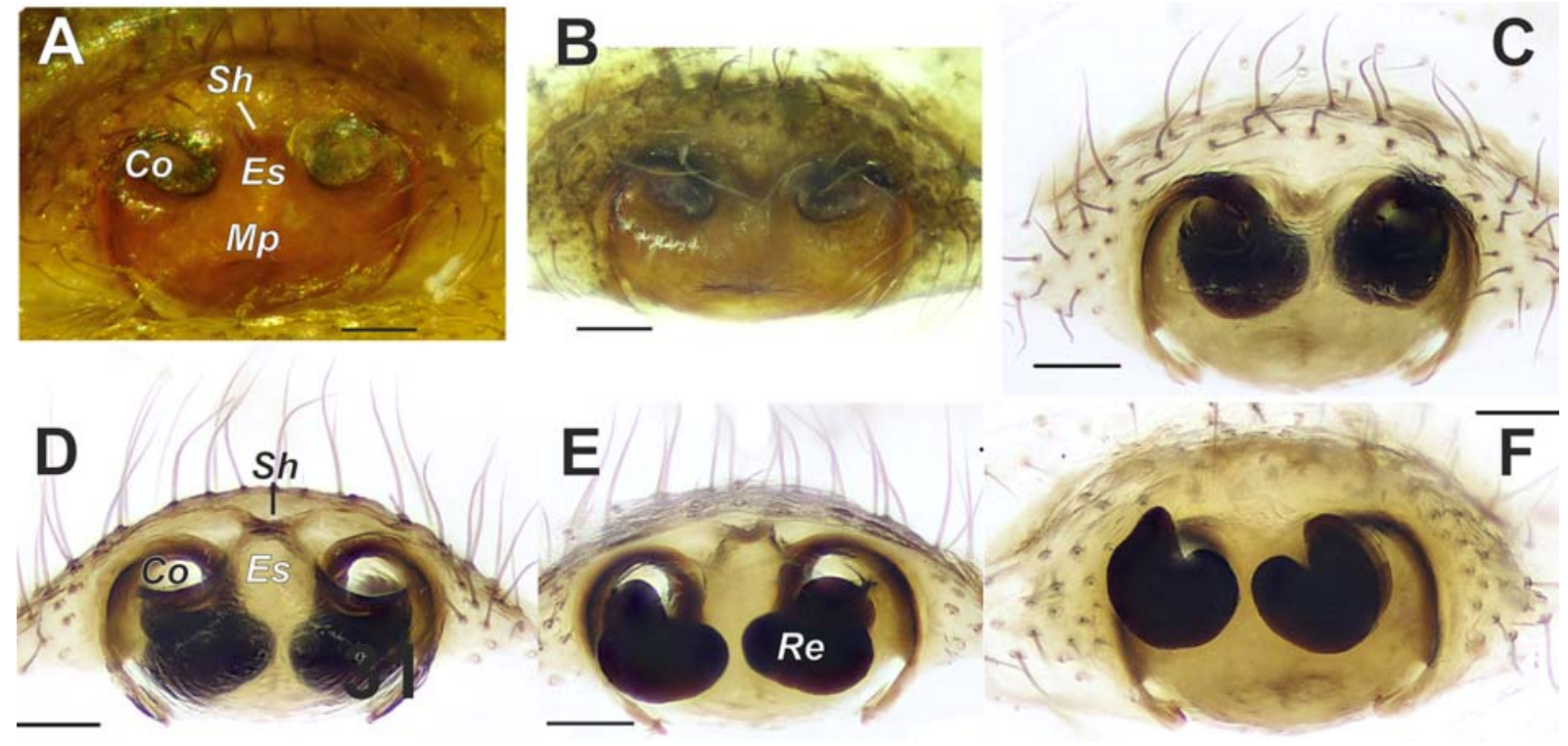

Fig. 5. Epigyne of Sinolinyphia henanensis. A - intact, ventral; B - dissected, antero-ventral; C-F - macerated, ventral, posterior, dorso-anterior and dorsal. Scale $0.1 \mathrm{~mm}$.

Abbreviations: $C o$ - copulatory opening, Es — stalk of median plate, $M p$ - median plate, Re receptacle, $S h$ — hood of the stalk.

Рис. 5. Эпигина Sinolinyphia henanensis. А — интактная, вентрально; В - вырезанная, спереди-вентрально; С - мацерированная, вентрально; D - мацерированная, сзади, Е - дорзально-спереди; F — дорзально. Масштаб 0,1 мм.

Сокращения: Co - копулятивное отверстие, $E s$ - ножка медиальной пластинки, $M p$ - медиальная пластинка, $R e-$ рецептакула, $S h$ - карман ножки.

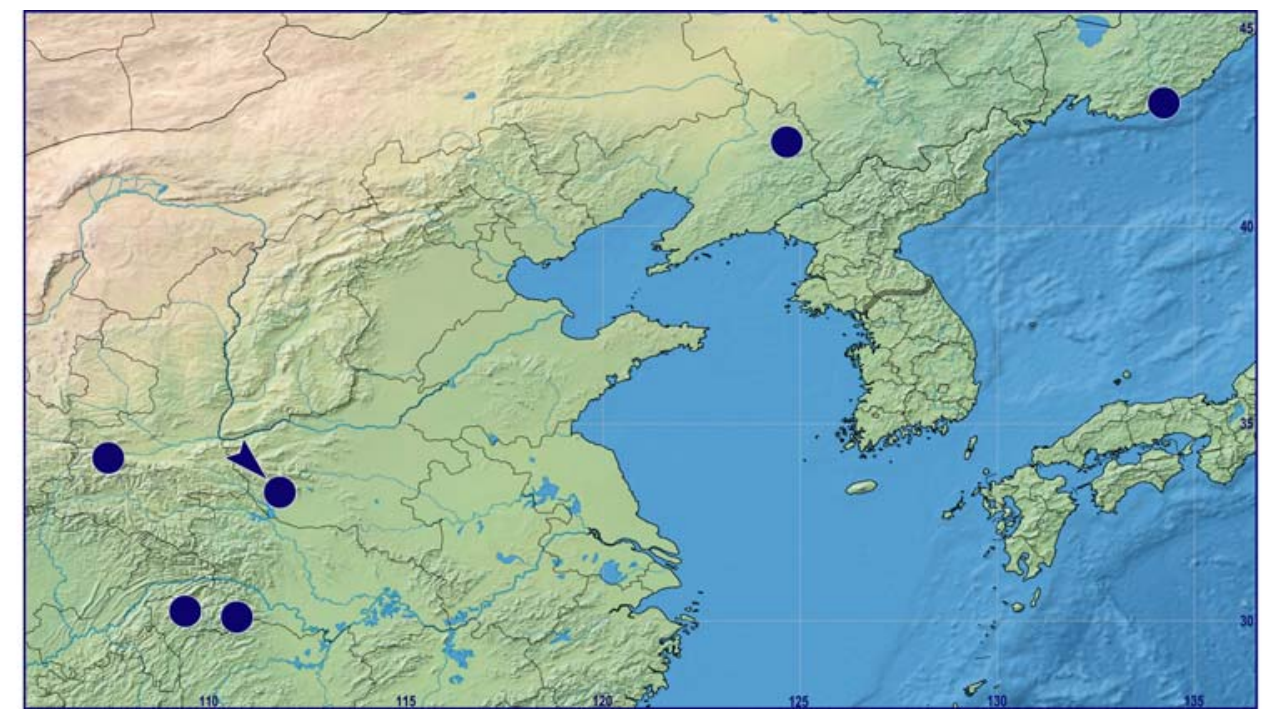

Fig. 6. Distribution records of Sinolinyphia henanensis. Arrow indicates type locality.

Fig. 6. Находки Sinolinyphia henanensis. Стрелка указывает типовое местообитание.

patella 1.6 times longer than wide, with one strong and straight seta as long as patella; tibia subconical, ca 1.4 times longer than wide, and as long as dorsal side of patella; cymbium droplet-shaped, with conical tip, about 2 times longer than wide; paracymbium small, 2 times shorter than width of tibia, triangular, lacking setae, connected to cymbium via membranous stalk; bulb suboval; tegulum small, partly hidden by ectal arm of lamella $(E a)$; lamella $(L a)$ wider than long, with long roundly bent at about $180^{\circ}$ ectal arm, pointed, partly covering ventral margin of tegulum, ental arm not developed, tail piece ( $T p$ ) of lamella short, about as long as ectal arm's width near base; embolus ( $E m)$ long, coiled clockwise at more than $360^{\circ}$ loop.

Female. Total length 5.4. Carapace 2.15 long, wide 1.45; fovea almost indistinct, very shallow.

Spination: tibia II 1r, other tibiae without lateral spines.

Coloration as in male, but abdomen grayish, with thin brown median stripe, sides blackish. Dorsum of abdomen longer than venter, posterior part of dorsum with conical 
extension. Postgastrum covered with sparse short subdecumbent setae.

Leg coloration as in male but more contrasting, femora I-II with gray spots.

Measurements of leg: I: $7.5(2.1,0.53,1.75,1.95,1.18)$, II: 6.48 (1.85, 0.58, 1.5, 1.63, 0.93), III: 4.68 (1.38, 0.5, 1.0, $1.15,0.65)$, IV: $7.05(2.13,0.53,1.53,2.0,0.88)$.

Epigyne as in Fig. 5A-F; plate oval, almost 2 times wider than long; median plate $(M p)$ anchor-shaped, with stalk (Es) about $1 / 3$ of median plate's width, anterior part of stalk with small hood $(\mathrm{Sh})$; copulatory openings $(\mathrm{Co})$ distinct, oval, about twice wider than long; copulatory ducts short, leading to bean- or c-shaped receptacles $(R e)$.

NOTE. Male palp of our specimen has no differences with those illustrated by Wunderlich \& Li (1995), but copulatory openings and receptacles are slightly different: copulatory openings in paratypes are round (not oval), smaller and spaced more widely, and receptacles are tube-shaped and coiled, forming $360^{\circ}$ loop. Figure of epigyne of the holotype is more similar to our specimen.

Acknowledgments. We thank Don Buckle (Saskatoon, Canada) and Alireza Zamani (Turku, Finland) for reviewing manuscript and editing English; Alexander A. Fomichev (Barnaul, Russia) for providing constructive suggestions on an earlier draft of the manuscript; Ilari E. Sääksjärvi (Turku, Finland) for allowing to use museum facilities; Peter van Helsdingen (Leiden, Netherlands) for the permission to use his figures.

\section{References}

Hu J.L., Wang Z.Y., Wang Z.G. 1991. Notes on nine species of spiders from natural conservation of Baotianman in Henan Province, China (Arachnoidea: Araneida) // Henan Science. Vol.9. No.2. P.37-52.

Marusik Yu.M.2009a. A check-list of spiders (Aranei) from the Lazo Reserve, Maritime Province, Russia // Arthropoda Selecta. Vol.18. No.1-2. P.95-109.

Marusik Yu.M. 2009b. [Order Aranei - Spiders] // Nasekomye Lazonskogo zapovednika. Vladivostok: Dal'nauka. P.380-392 [in Russian].

Oliger T.I., Marusik Yu.M., Koponen S. 2002. New and interesting records of spiders (Araneae) from the Maritime Province of Russia // Acta Arachnologica. Vol.51. No.2. P.93-98.

Song D.X., Zhu M.S., Chen J. 1999. The spiders of China. Shijiazhuang: Hebei Science and Technology Publishing House. 640 p.

Wunderlich J., Li S.Q. 1995. Three new spider species and one new genus (family Linyphiidae) from China (Arachnida: Araneae) // Beiträge zur Araneologie. Bd.4 (1994). P.335-342.

Yin C.M., Wang J.F., Zhu M.S., Xie L.P., Peng X.J., Bao Y.H. 1997. Fauna Sinica: Arachnida: Araneae: Araneidae. Beijing: Science Press. $460 \mathrm{p}$

Yin C.M., Peng X.J., Yan H.M., Bao Y.H., Xu X., Tang G., Zhou Q.S., Liu P. 2012. Fauna Hunan: Araneae in Hunan, China. Changsha: Hunan Science and Technology Press. 1590 p.

Zhu M.S., Zhang J.X., Zhang Z.S., Chen H.M. 2005. Arachnida: Araneae // Yang M.F. \& D.C. Jin (eds.). Insects from Dashahe Nature Reserve of Guizhou. Guiyang: Guizhou People's Publishing House. P.490-555.

Zhu M.S., Zhang B.S. 2011. Spider Fauna of Henan: Arachnida: Araneae. Beijing: Science Press. 558 p.

Responsible editor K.G. Mikhailov 